\title{
Analiza toksykologiczna peptydów w materiale biologicznym z wykorzystaniem spektrometrii mas na przykładzie oznaczania alfa-amanityny
}

\author{
Amanitine determination as an example of peptide analysis in the biological samples \\ with HPLC-MS technique
}

\author{
Tomasz Janus, Ewa Jasionowicz, Barbara Potocka-Banaś, Krzysztof Borowiak ${ }^{\bowtie}$ \\ Pomorski Uniwersytet Medyczny w Szczecinie, Katedra Medycyny Sądowej, Zakład Toksykologii Klinicznej i Sądowej, al. Powstańców Wlkp. 72, 70-111 Szczecin \\ $\triangle$ boroks@pum.edu.pl
}

\begin{abstract}
Introduction: Routine toxicological analysis is mostly focused on the identification of non-organic and organic, chemically different compounds, but generally with low mass, usually not greater than 500-600 Da. Peptide compounds with atomic mass higher than 900 Da are a specific analytical group. Several dozen of them are highly-toxic substances well known in toxicological practice, for example mushroom toxin and animal venoms. In the paper the authors present an example of alpha-amanitin to explain the analytical problems and different original solutions in identifying peptides in urine samples with the use of the universal LC MS/MS procedure.

Materials and methods: The analyzed material was urine samples collected from patients with potential mushroom intoxication, routinely diagnosed for amanitin determination. Ultra filtration with centrifuge filter tubes (limited mass cutoff $3 \mathrm{kDa}$ ) was used. Filtrate fluid was directly injected on the chromatographic column and analyzed with a mass detector (MS/MS).
\end{abstract}

Results: The separation of peptides as organic, amphoteric compounds from biological material with the use of the SPE technique is well known but requires dedicated, specific columns. The presented paper proved that with the fast and simple ultra filtration technique amanitin can be effectively isolated from urine, and the procedure offers satisfactory sensitivity of detection and eliminates the influence of the biological matrix on analytical results. Another problem which had to be solved was the non-characteristic fragmentation of peptides in the MS/MS procedure providing non-selective chromatograms. It is possible to use higher collision energies in the analytical procedure, which results in more characteristic mass spectres, although it offers lower sensitivity.

Conclusions: The ultra filtration technique as a procedure of sample preparation is effective for the isolation of amanitin from the biological matrix. The monitoring of selected mass corresponding to transition with the loss of water molecule offers satisfactory sensitivity of determination.

Keywords: alpha-amanitin; peptides; LC-MS/MS.

\begin{abstract}
ABSTRAKT
Wstęp: Rutynowa analiza toksykologiczna materiału biologicznego obejmuje najczęściej badania w kierunku identyfikacji związków o różnym charakterze, właściwościach i budowie organicznej lub nieorganicznej, jednak o masie nieprzekraczającej 500-600 Da. Większość związków organicznych to cząstki o stosunkowo niewielkiej masie. Zupełnie odmienną grupą analityczną są związki o budowie peptydowej i masie przekraczającej 900 Da, będące składnikami wielu toksyn, szczególnie grzybów kapeluszowych czy jadów zwierzęcych.

Celem pracy było przedstawienie analitycznej specyfiki związków o strukturze peptydowej na przykładzie alfa-amanityny, oznaczanych w powszechnie stosowanych układach LC-MS/MS, na podstawie badań własnych.

Materiały i metody: Materiał badawczy stanowił mocz pobierany od pacjentów w ramach rutynowej diagnostyki zatruć grzybami, analizowany pod kątem obecności alfa-amanityny. Mocz poddany został ultrafiltracji na filtrach wirówkowych o odcięciu masowym $3 \mathrm{kDa}$; przesącz poddano bezpośredniej analizie chromatograficznej z detekcją mas.
\end{abstract}

Wyniki: Peptydy jako grupa związków organicznych wykazujących właściwości amfoteryczne przy stosunkowo dużej masie cząsteczkowej mogą być ekstrahowane w układzie fazy stałej, jednak na dedykowanych kolumnach. W pracy wykazano, iż zastosowanie ultrafiltracji na etapie przygotowania próbek do analizy pozwala na skuteczną izolację alfa-amanityny, przy zachowaniu wymaganej czułości oznaczenia i ograniczeniu wpływu matrycy na sprawność układu analitycznego. Specyfiką peptydów jest także ich mało charakterystyczna fragmentacja, skutkująca jedynie intensywnym sygnałem o masie M-18. Wykorzystanie tego przejścia masowego w trybie pomiaru MS/MS nie pozwala jednak na uzyskanie całkowicie selektywnego chromatogramu. Zastosowanie wyższych energii kolizyjnych prowadzi do uzyskania bardziej charakterystycznego widma masowego, jednak skutkuje to jednoczesnym spadkiem czułości oznaczenia. Wnioski: Ultrafiltracja jako etap przygotowania próbek w analizie alfa-amanityny jest efektywną metodą izolacji peptydów z matrycy. Monitoring przejścia masowego w trybie MS/MS z utratą cząsteczki wody pozwala na uzyskanie wysokiej czułości oznaczenia. Słowa kluczowe: alfa-amanityna; peptydy; LCMS. 


\section{WSTEP}

Współczesnym problemem toksykologii klinicznej jest gwałtownie wzrastająca liczba związków wykazujących wysoką aktywność biologiczną w bardzo niskich stężeniach. Wymusza to ciągłe poszukiwanie bardziej czułych i selektywnych metod analitycznych oraz technik izolacji ksenobiotyków. Obecnie już ponad 20 mln związków chemicznych znajduje się w oficjalnych światowych wykazach. Ocenia się, że ok. 200 tys. z nich to praktycznie powszechnie dostępne substancje o różnym charakterze kwasowo-zasadowym, budowie organicznej lub nieorganicznej, stanowiące potencjalne zagrożenie toksykologiczne [1]. Większość związków organicznych, takich jak: alkohole, rozpuszczalniki, środki ochrony roślin, substancje wykazujące działanie narkotyczne i ich nowo projektowane analogi funkcjonalne i strukturalne, to molekuły o stosunkowo niewielkiej masie, która nie przekracza 500-600 Da (daltonów) [2].

Do odmiennej grupy analitycznej należą ksenobiotyki o budowie peptydowej i masie przekraczającej 900 Da [3], będące składnikami wielu toksyn, szczególnie grzybów kapeluszowych oraz jadów zwierzęcych. Zatrucia grzybami kapeluszowymi, jakkolwiek mają charakter sezonowy, stanowią aktualny problem epidemiologiczny i toksykologiczny. Szczególne zainteresowanie z uwagi na przebieg kliniczny zatrucia i stosunkowo dużą śmiertelność budzą bicykliczne peptydowe toksyny (amanityny, falo toksyny) grzybów z gatunku Amanita phalloides i pokrewnych $(A$. verna, $A$. virosa) $[4,5]$. W praktyce podstawą rozpoznania zatrucia, obok obserwowanych objawów klinicznych, nadal jest identyfikacja mikroskopowa zarodników w treści przewodu pokarmowego oraz coraz częściej analityczne potwierdzenie obecności w moczu głównej toksyny - alfa-amanityny [6, 7].

Tandemowa spektrometria mas sprzężona z chromatografią cieczową uważana jest obecnie za metodę z wyboru w badaniach proteomicznych i analizie peptydów $[3,6]$. Specyfiką peptydów jest także ich mało charakterystyczna fragmentacja, skutkująca jedynie intensywnym sygnałem o masie M-18. Wykorzystanie tego przejścia masowego w trybie pomiaru MS/MS nie pozwala jednak na uzyskanie całkowicie selektywnego chromatogramu, z uwagi na współobecność wielu innych peptydów o masie $<3 \mathrm{kDa}$, interferujących w pomiar. Zastosowanie wyższych energii kolizyjnych prowadzi do uzyskania bardziej charakterystycznego widma masowego, jednak skutkuje to jednoczesnym spadkiem czułości oznaczenia [6].

\section{MATERIAŁY I METODY}

Materiał stanowiły próbki moczu pobierane od pacjentów w ramach rutynowej diagnostyki zatruć grzybami (badanie sporologiczne w popłuczynach żołądkowych i w kale). Mocz wirowano (14 tys. obrotów/min) przez 5 min, uzyskany supernatant w ilości 0,5 mL nanoszono na filtr wirówkowy o selektywnym odcięciu masowym 3kDa (Amicon Ultra - 0,5 nr kat. UFC500396, Merck Millipore) i ponownie wirowano przez 10 min (12 tys. obrotów/min). Przesącz po odwirowaniu rozcieńczono wodą z dodatkiem 0,1\% objętościowego kwasu mrówkowego ( $\mathrm{HCOOH}$ ) i poddawano bezpośredniej analizie chromatograficznej.

Rozdział chromatograficzny prowadzono z wykorzystaniem chromatografu cieczowego firmy Eksigent Ekspert UltraLC 110XL, na kolumnie monolitycznej Chromolithic ${ }^{\circledR}$ Performance RP-18e 100 - 2 mm (Merck), w trybie gradientowym, objętość nastrzyku $25 \mu \mathrm{L}$. Faza ruchoma $(0,4 \mathrm{~mL} / \mathrm{min})$ : woda $(\mathrm{A})$ - acetonitryl (B) z dodatkiem 0,1\% $\mathrm{HCOOH}$. Czas rozdziału $10 \mathrm{~min}$, gradient 0-0,5 min 95\% A, 6 min 5\% A, 8 min 5\% A, 8,2 min 95\% A, 10 min 95\% A.

Chromatograf sprzężono z wysokorozdzielczym spektrometrem mas typu QqTOF firmy AB Sciex model TripleTOF 5600+. Próbki analizowano po kalibracji zewnętrznej i jonizacji w źródle typu DuoSpray (ESI - próbka; APCI - roztwór kalibracyjny), w trybie fragmentacji wybranych jonów pseudomolekularnych (MS/MS ${ }^{\mathrm{HR}}$ ).

\section{WYNIKI}

Peptydy jako grupa związków organicznych wykazujących właściwości amfoteryczne przy stosunkowo dużej masie cząsteczkowej mogą być ekstrahowane w układzie fazy stałej, jednak na dedykowanych kolumnach, o innych właściwościach niż stosowane powszechnie do ekstrakcji związków niskocząsteczkowych. Ich bardzo dobra rozpuszczalność w wodzie, bez względu na zmiany $\mathrm{pH}$, ogranicza zastosowanie ekstrakcji ciecz-ciecz. W przeciwieństwie do białek peptydy nie ulegają typowym przemianom, jak wytrącanie z roztworu poprzez wysalanie, dodatek rozpuszczalnika czy soli metali ciężkich.

Z uwagi na przedstawione problemy podjęto próbę zastosowania własnej procedury z wykorzystaniem filtrów probówkowych o ustalonym punkcie odcięcia masy. Przedstawione w pracy wyniki badań wskazują, iż zastosowanie ultrafiltracji na etapie przygotowania próbek do analizy pozwala na skuteczną izolację alfa-amanityny, przy zachowaniu wymaganej czułości oznaczenia, a co ważne - przy jednoczesnym ograniczeniu wpływu matrycy na sprawność układu analitycznego (ryc. 1 i 2).

Kolejnym problemem wymagającym analitycznego rozwiązania była przewidywana i typowa dla peptydów mało charakterystyczna fragmentacja oznaczanego ksenobiotyku, skutkująca jedynie intensywnym sygnałem o masie M-18. Już wcześniej badacze zwracali uwagę, że w przypadku związków peptydowych wykorzystanie przejścia masowego w trybie pomiaru MS/MS nie pozwala na uzyskanie całkowicie selektywnego chromatogramu, z uwagi na współobecność w materiale biologicznym wielu innych peptydów o masie $<3 \mathrm{kDa}$, interferujących w pomiar [6].

Jednocześnie, jak można było przewidywać, zastosowanie wyższych energii kolizyjnych prowadziło do uzyskania bardziej charakterystycznego widma masowego, co skutkowało jednak jednoczesnym spadkiem czułości oznaczenia (ryc. 3-7). 


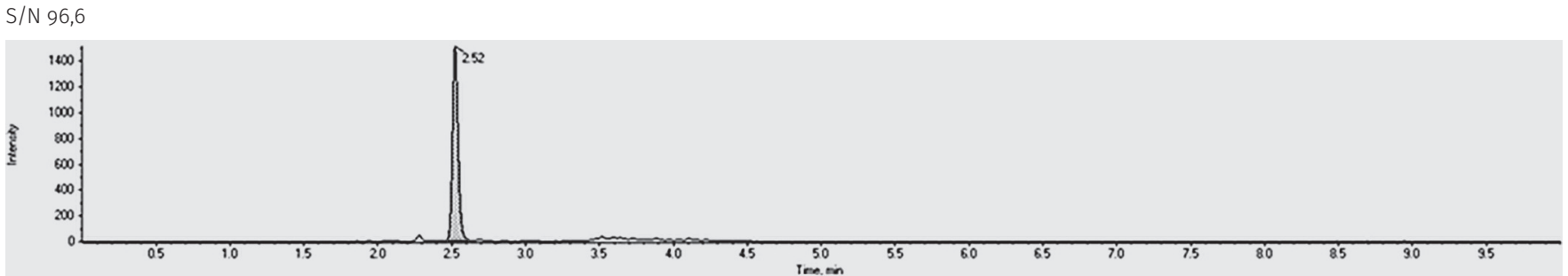

RYCINA 1. Chromatogram wybranego prądu jonowego dla przejścia 919,3-901,35 $\pm 0,05$; wzorzec alfa-amanityny w stężeniu $10 \mathrm{ng} / \mathrm{mL}$

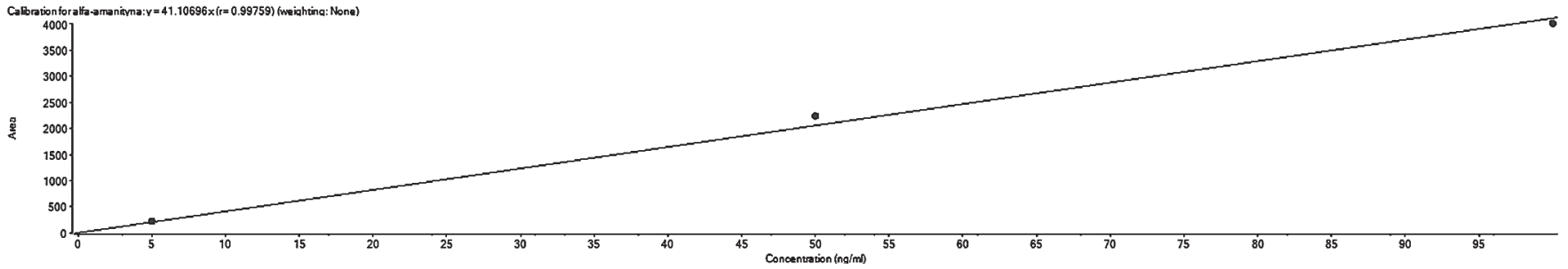

Punkty kalibracyjne: 0,5 ng/mL; $50 \mathrm{ng} / \mathrm{mL} ; 100 \mathrm{ng} / \mathrm{mL}(\mathrm{Y}=41 \mathrm{X}, \mathrm{r}=0,9976)$

RYCINA 2. Krzywa kalibracyjna dla alfa-amanityny
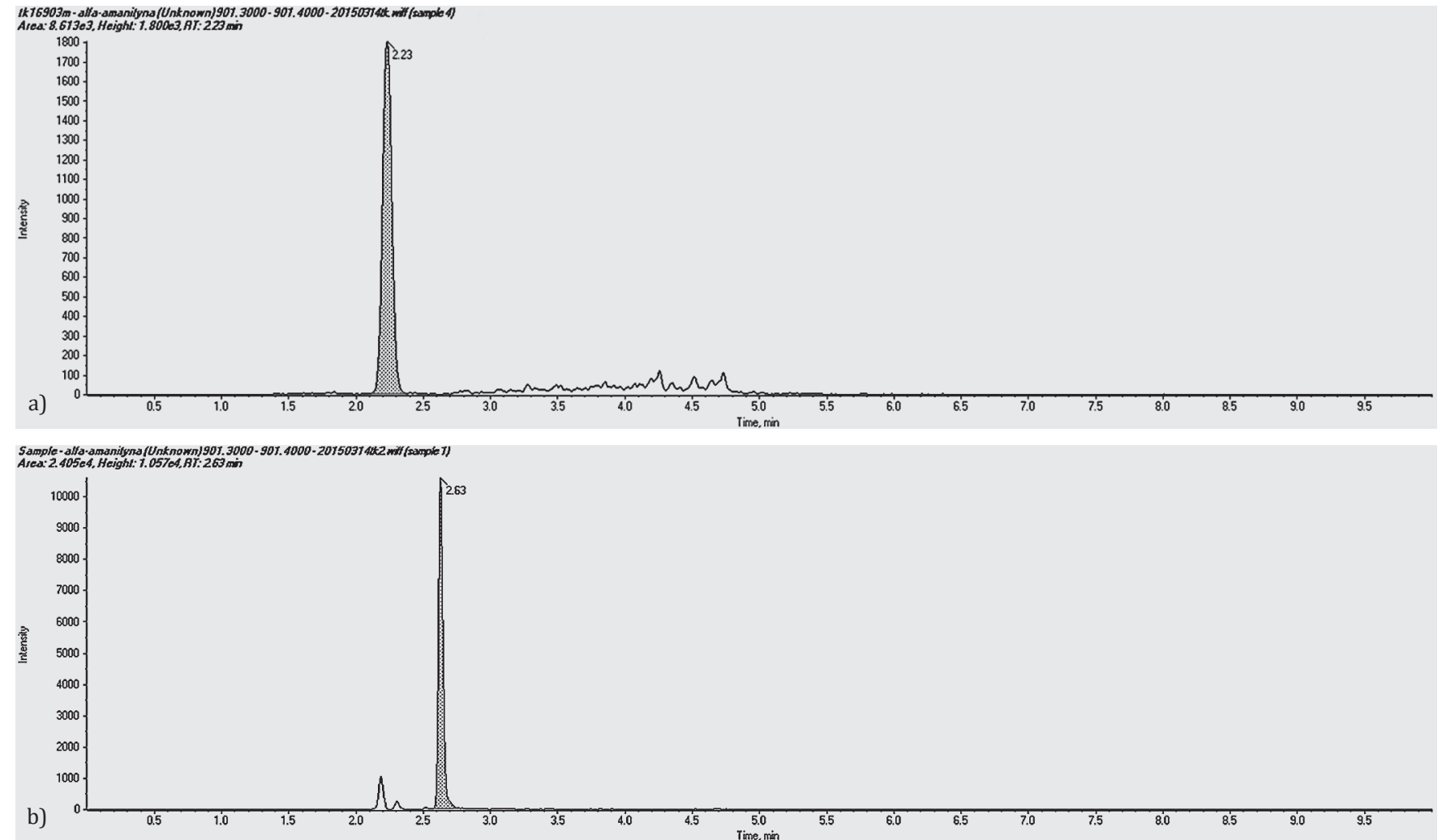

RT - czas retencji

RYCINA 3. Podejrzenia zatrucia muchomorem (wywiad - spożycie płachetki kołpakowatej), analiza w kierunku alfa-amanityny: a) chromatogram próbki badanej MS/MS: 919,3-901,35 £0,05; b) mocz badany z dodatkiem alfa-amanityny $100 \mathrm{ng} / \mathrm{mL}$ (Delta RT - 0,4 min)

\section{DYSKUSJA}

Wybór i przygotowanie optymalnej metody izolacji ksenobiotyku, zapewniającej uzyskiwanie powtarzalnych i pewnych wyników, które nadają się do interpretacji i wnioskowania klinicznego, jest w analizie toksykologicznej istotnym wyzwaniem. Najczęściej stosowaną w praktyce toksykologicznej metodą izolacji ksenobiotyków jest ekstrakcja typu ciecz-ciecz. W przypadku związków peptydowych z uwagi na ich bardzo dobrą rozpuszczalność w wodzie (bez względu na zmiany $\mathrm{pH}$ ) zastosowanie ekstrakcji ciecz-ciecz jest mocno ograniczone. W przeciwieństwie do białek, peptydy nie ulegają także typowym reakcjom stosowanym w analizie preparatywnej, jak: wytrącanie z roztworu poprzez wysalanie, dodatek nadmiaru rozpuszczalnika czy soli metali ciężkich. Według wielu badaczy związki peptydowe mogą być również 


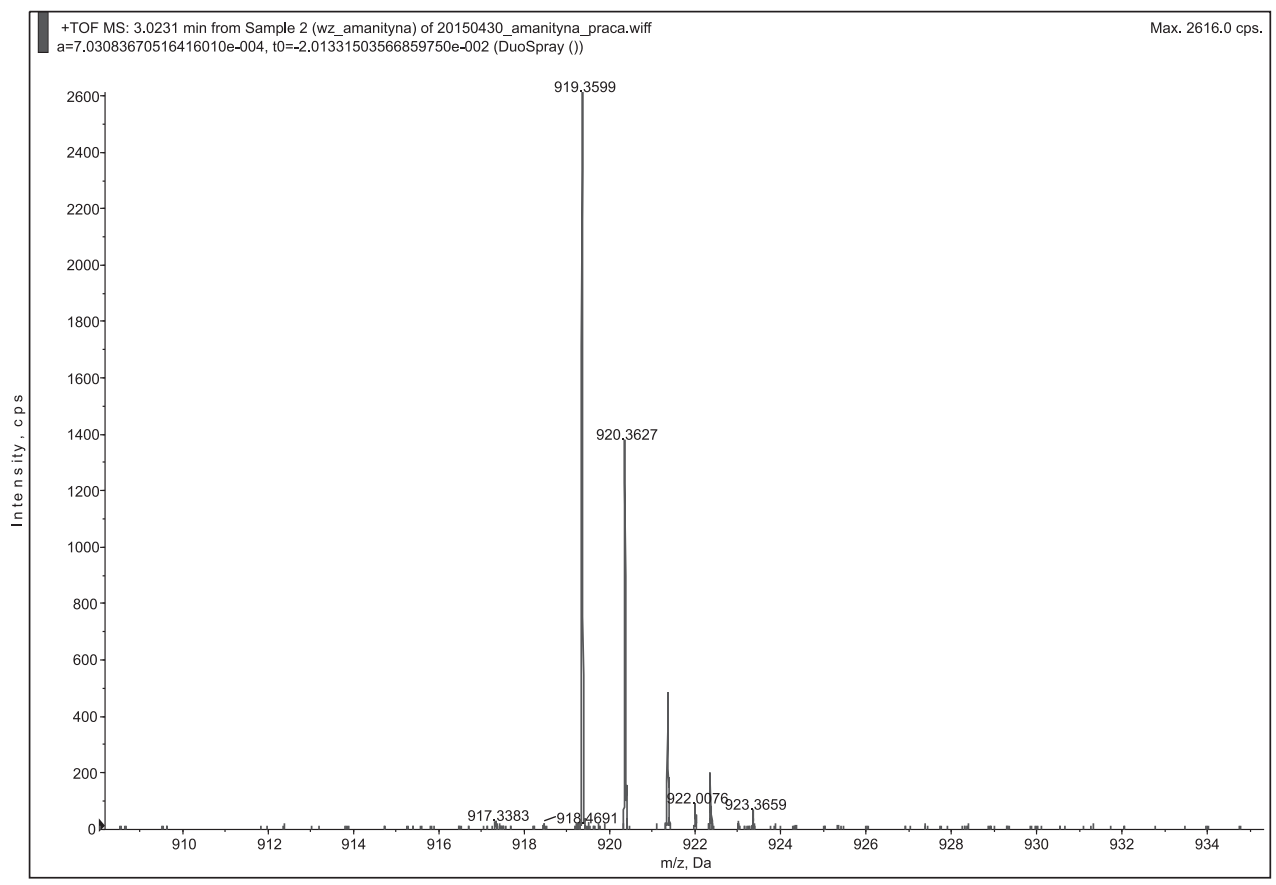

RYCINA 4. Spektrogram amanityny w trybie TOF $(919,3599)$

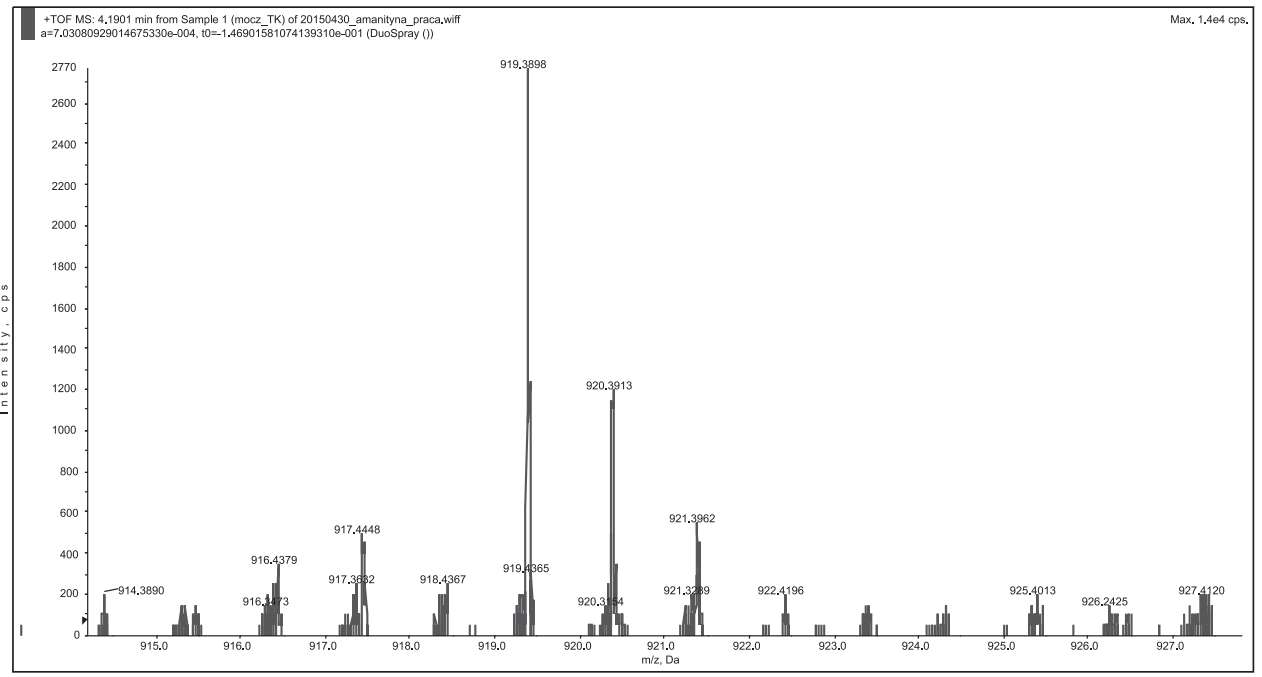

delta MS - 0,0299

RYCINA 5. Skan w trybie TOF - interferencja matrycy biologicznej $(919,3898)$

frakcjonowane elektroforetycznie na żelu lub ekstrahowane w układzie fazy stałej, co wymaga jednak zastosowania dedykowanych kolumn separacyjnych o odmiennej charakterystyce niż stosowane rutynowo do ekstrakcji związków niskocząsteczkowych $[3,8,9,10]$.

Przedstawione wynik badań własnych wskazują na możliwość zastosowania dla izolacji peptydów na etapie przygotowania próbek do analizy metody ultrafiltracji. Jak się okazało, ta dotychczas rzadko stosowana technika pozwala na skuteczną izolację alfa-amanityny i zachowanie wymaganej czułości oznaczenia, przy jednoczesnym ograniczeniu wpływu matrycy na sprawność układu analitycznego. Podobne rozwiązania w ostatnich latach próbowali zastosować Nomura i wsp. [10].
Odrębny problem analityczny przedstawiony w pracy, a wynikający ze specyficznych cech grupy peptydów, stanowiła także ich mało charakterystyczna fragmentacja masowa skutkująca jedynie intensywnym sygnałem o masie M-18. Wykorzystanie tego przejścia masowego w trybie pomiaru MS/MS nie pozwala jednak na uzyskanie całkowicie selektywnego chromatogramu z uwagi na współobecność wielu peptydów endogennych o masie <3 kDa, interferujących w przeprowadzany pomiar. Ten problem poruszany jest przez większość badaczy zajmujących się proteomiką [2, 6, 9]. Jednym z możliwych rozwiązań jest zastosowanie wyższych energii kolizyjnych, co pozwala na uzyskanie bardziej charakterystycznego widma masowego. Zaznaczyć jednak należy, że taka zmiana skutkuje 
a)
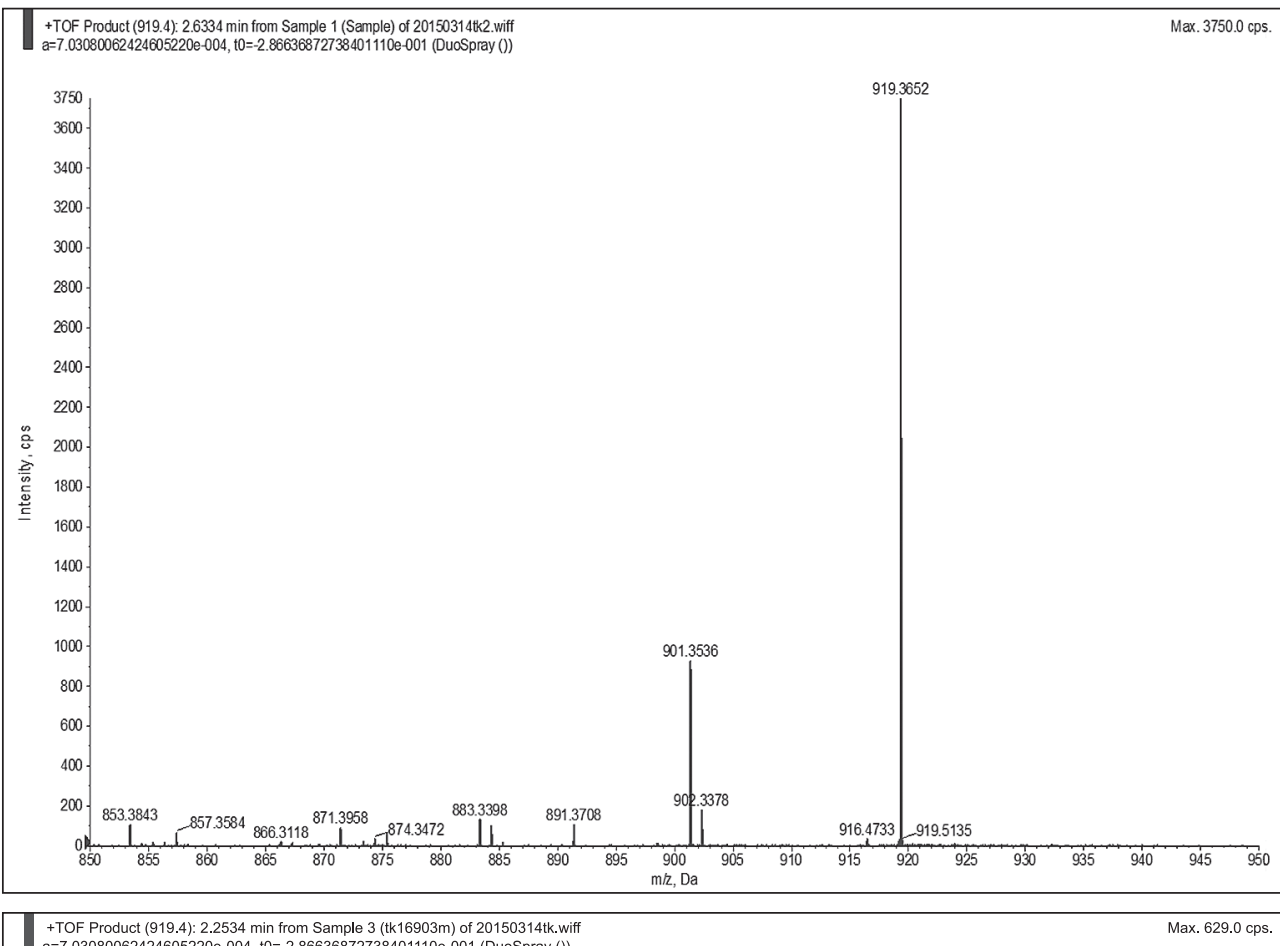

+TOF Product (919.4): $2.2534 \mathrm{~min}$ from Sample 3 (tk16903m) of 20150314tk. w

Max. $629.0 \mathrm{cps}$.

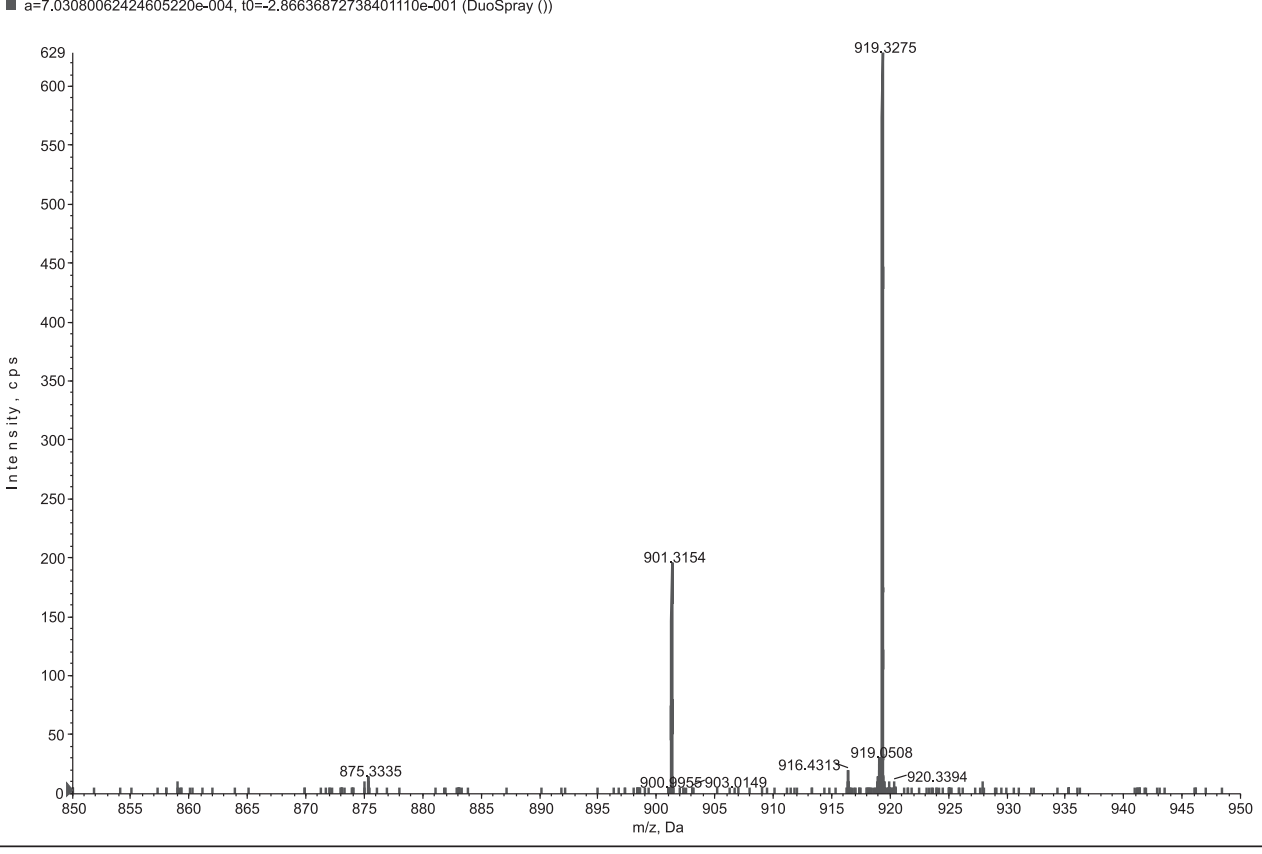

RYCINA 6. Skan alfa-amanityny oraz próbki badanej w trybie MS/MS: a) wzorzec amanityny; b) próbka badana

jednoczesnym spadkiem czułości oznaczenia. Należy zwrócić uwagę na możliwość rejestracji, a zatem interferencję w wynik pików tła biologicznego [9]. Wymaga to dokładnej i krytycznej oceny uzyskiwanych chromatogramów, jakkolwiek bowiem różnice czasów retencji mogą być niewielkie, to eluują one w innym czasie, dlatego istnieje możliwość ich rozróżnienia.

Reasumując, przygotowanie procedury dla efektywnej, toksykologicznej analizy peptydowych toksyn wymaga od analityka krytycznej oceny przyjętych warunków, uwzględniających optymalną metodę izolacji, a także stosowanie selektywnych detektorów masowych i wysokorozdzielczych kolumn chromatograficznych.

\section{WNIOSKI}

1. Ultrafiltracja jako etap przygotowania próbek w analizie alfa-amanityny jest prostą, szybką i efektywną metodą izolacji peptydów z matrycy.

2. Monitoring przejścia masowego w trybie MS/MS z utratą cząsteczki wody pozwala na uzyskanie wysokiej czułości oznaczenia.

3. Istotne znaczenie dla skutecznej analizy peptydów może mieć używanie wysokorozdzielczych kolumn chromatograficznych, a nie tylko selektywnych detektorów masowych. 
a)

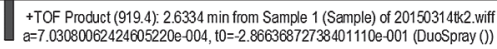

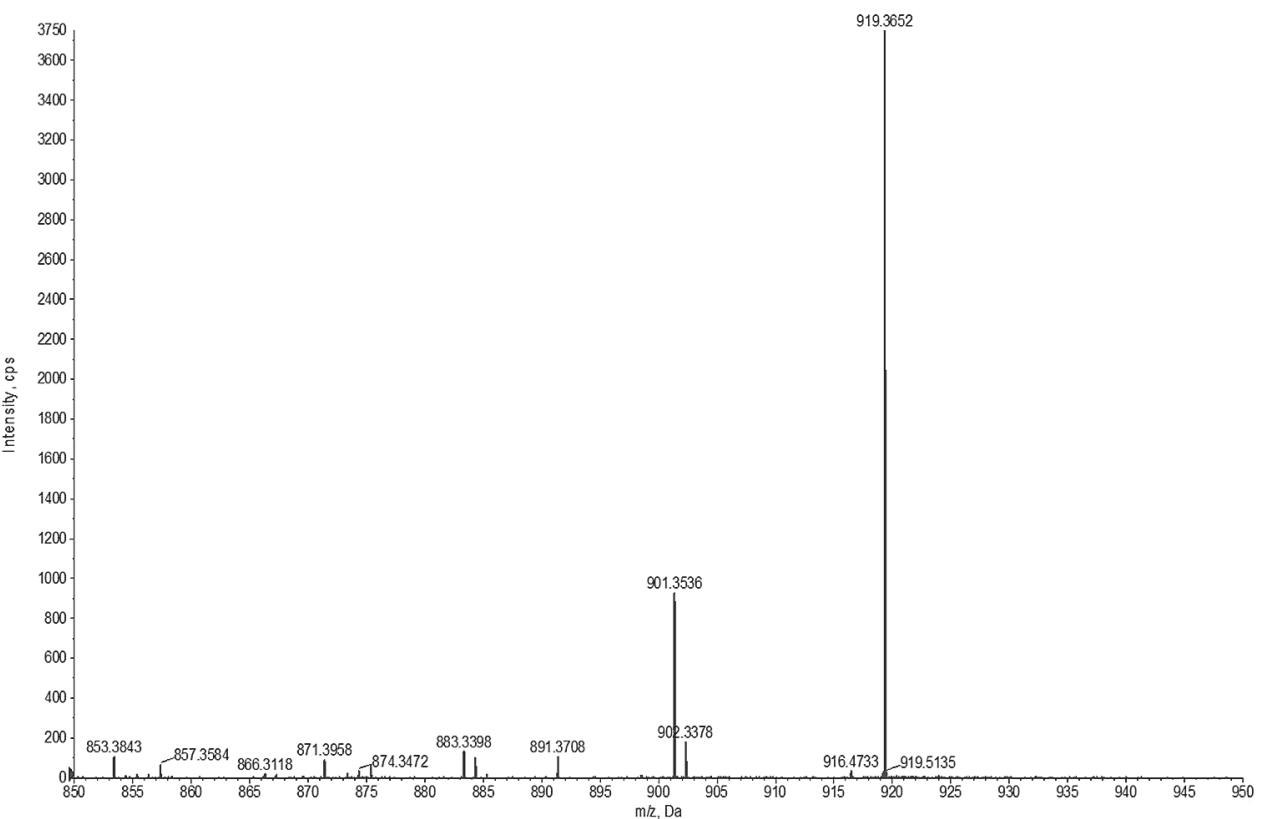

+ TOF Product (919.4): 2.2534 min from Sample 3 (tk169003m) of 20150314tk.wif
$\mathrm{a}=7.03080062424605220 \mathrm{e}-004$, to $=-2.86636872738401110 \mathrm{e}-001$ (DuoSpray ())

Max. $629.0 \mathrm{cps}$
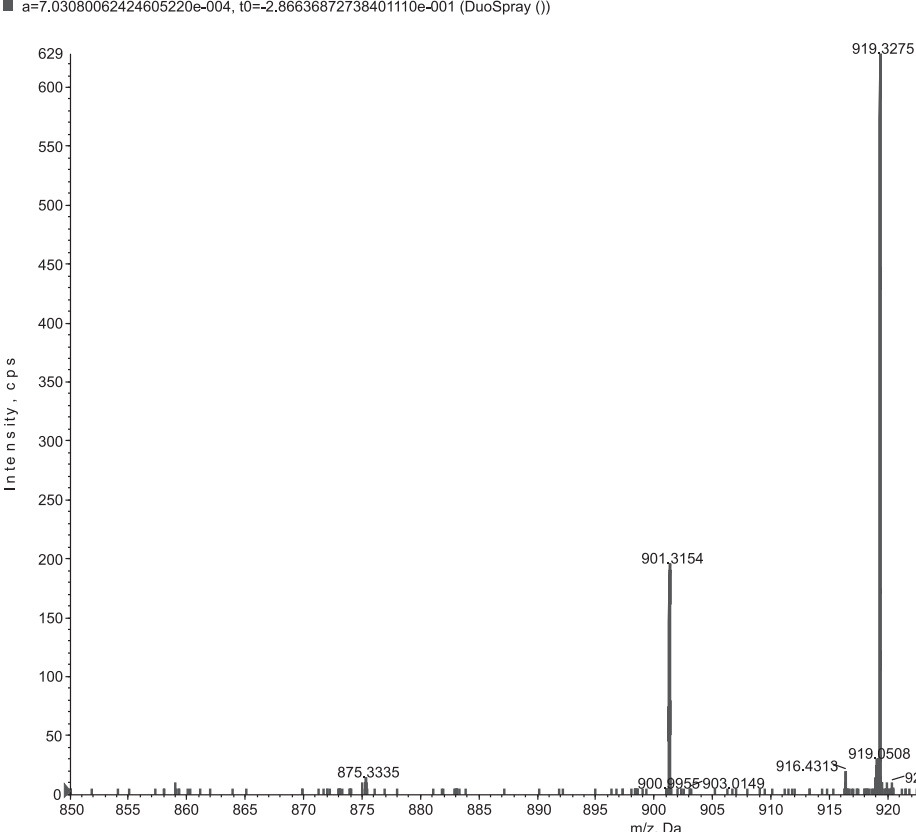

RYCINA 7. Skan alfa-amanityny i próbki badanej w trybie MS/MS ilustrujący wzrost selektywności i jednoczesny spadek czułości oznaczenia: a) wzorzec amanityny; b) próbka badana

\section{PIŚMIENNICTWO}

1. Machoy-Mokrzyńska A, Potocka B, Borowiak K. Podstawowe pojęcia toksykologiczne, drogi narażenia, losy trucizny w ustroju, odtrutki. In: Borowiak KS, Machoy-Mokrzyńska A, editors. Wybrane zagadnienia z toksykologii ogólnej i ostrych zatruć. Szczecin: Wydawnictwo Pomorskiej Akademii Medycznej w Szczecinie; 2003. p. 6-9.

2. Badcock NR. Detection of poisoning by substances other than drugs: a neglected art. Ann Clin Biochem 2000;37(2):146-57.

3. Bonk T, Humeny A. MALDi-TOF-MS analysis of protein and DNA. Neuroscientist 2001;7(1):6-12.

4. Wieland T, Faulstich H. Amatoxins, phallotoxins, phallolysin and antamanidine: the biologically active components of poisonous Amanita mushroom. CRC Crit Rev Biochem 1978;5(3):185-260.
5. Wieland T. The toxic peptides from Amanita mushrooms. Int J Pept Protein Res 1983;22(3):257-76.

6. Meyers A, Trauger S, Webb W, Reisdorph N, Wranick C, Peters E, et al. Protein identification and profiling with mass spectrometry. Spectroscopy 2003;17:1-15

7. Dorizzi R, Michelot D, Tagliaro F, Ghielmi S. Methods for chromatographic determinations of amanitins and related toxins in biological samples. J Chromatogr 1992;580(1-2):279-91.

8. Domon B, Aebersold R. Mass spectrometry and protein analysis. Science 2006;312:212-7.

9. Finoulst I, Pinkse M, van Dongen W, Verhaert P. Sample preparation techniques for the untargeted LC-MS-based discovery of peptides in complex biological matrices. J Biomed Biotechnol 2011; 245291. doi: $10.1155 / 2011 / 245291$. 
10. Nomura M, Suzuki Y, Kaneko R, Ogawa T, Hattori H, Seno H, et al. Simple and rapid analysis of amatoxins using UPLC-MS-MS. Forensic Toxicol 2012;30(2):185-92.

\section{KOMENTARZ}

W artykule przedstawiono wyniki badań dotyczących wykonywania spektometrii mas do oznaczania alfa-amanityny, związku o strukturze peptydowej i masie przekraczającej 900 Da. Związki o takich właściwościach są składnikami wielu toksyn, zwłaszcza grzybów kapeluszowych.
Zagadnienie to jest więc niezwykle ważne i aktualne, tym bardziej, że w polskich warunkach, szczególnie w sezonie letnio-jesiennym, notuje się często nawet masowe zatrucia grzybami. Z metodycznego punktu widzenia na uwagę zasługuje wprowadzenie na etapie przygotowywania próbek moczu do analizy, ich ultrafiltracja, co pozwala na efektywną izolację peptydów. To jest nowy element o dużym znaczeniu utylitarnym. Artykuł wnosi nowe, ważne w zakresie diagnostyki toksykologicznej propozycje analityczne o dużym znaczeniu praktycznym.

prof. dr hab. Maciej Rogalski 